\title{
The Effect of Interpersonal Communication and Work Satisfaction on Teacher Performance at SD Negeri Bandar Baru, Pidie Jaya Aceh
}

\author{
Darmawati $^{1}$, Zainuddin ${ }^{2}$, Benyamin Situmorang $^{3}$, Nasrun ${ }^{4}$, Akmaluddin $^{5}$ \\ ${ }^{1}$ Universitas Serambi Mekkah, Indonesia \\ ${ }^{2,3,4}$ Postgraduate Program in Universitas Negeri Medan, Indonesia \\ ${ }^{5}$ Universitas Ubudiyah, Indonesia
}

\section{Abstract}

The purpose of this study is to determine and review: (1) teacher performance models that are built based on the associative causal relationship between exogenous variables and endogenous variables, (2) the effect of interpersonal communication on job satisfaction, (3) the effect of interpersonal communication on teacher performance, (4) the effect of satisfaction on teacher performance. This research was conducted in elementary schools with 154 respondents from 28 public elementary schools in Pidie Jaya. For questionnaire data collection with five alternative answer choices, while for the performance variable is done by observation using an observation sheet. The sampling technique used is proportional random sampling. The instrument used was preceded by a trial to respondents outside the sample to obtain a valid and relative instrument. Validity test uses product moment correlation, whereas to test its reliability with the Alpha formula from Cronbach. Before testing the hypothesis first, the analysis requirements test is calculated including the data normality test and the regression linearity test. The results showed (1) obtained by the teacher performance model, (2) Interpersonal communication had a direct positive effect on job satisfaction, (3) Interpersonal communication had a direct positive effect on teacher performance, (4)Job satisfaction had a positive direct effect on teacher performance. Based on the acceptance of research hypotheses, a theoretical model or fixed model is found that describes the structure of the causal relationship between Interpersonal Communication variables, organizational culture, job satisfaction, work motivation and teacher performance while to test its reliability with the Alpha formula from Cronbach.

Keywords

interpersonal communication; job satisfaction; teacher performance.

\section{Introduction}

National education is organized as a process of civilization and empowerment, where in that process it takes educators who can set an example and awaken the will and develop the potential of students in primary schools. Elementary School (SD) is part of a basic education institution that functions to instill values, attitudes, and a sense of beauty, as well as provide a basis of knowledge, and the ability to read, write, and count for students so they have the provision to continue their education in junior high schools (SMP). In connection with that, there are three missions carried by primary schools, namely carrying out the education process, the socialization process, and the transformation process. Education is one of the important things in human life. Along with the development of the era, education has become a necessity that must be met by the community. On the other hand, the level of education is also one of the benchmarks of the progress of a society, region, and country. Education in general can be interpreted as a 
process of personal development so that someone can still carry on life. Law Number 20 of 2003 concerning National Education System article 1 state:

Education is a conscious and planned effort to create an atmosphere of learning and learning process so that students actively develop their potential to have spiritual spiritual strength, self-control, personality, intelligence, noble character and the skills needed by themselves, society, nation and state.

The Directorate of Education Personnel explains that "teachers are an element of education that is very closely related to students in their daily education efforts at school and largely determines the success of students in achieving their goals." Ibrahim Bafadal (2017), explained that teachers are educators who have a strategic role in development in the field of national education. In connection with the description above, Wardiman Djoyonegoro in Mulyasa explained three main conditions that must be considered in the development of education in order to contribute to improving the quality of human resources, namely: (1) teachers and professional education staff; (2) building facilities; and (3) quality books. Enco Mulyasa (2018) explained So, Professional teachers are the main requirements that must be met so that education can successfully realize the goals of national education, the dignity and role of the teacher as an agent of learning functions to improve the quality of national education, Ramlan, et.al(2020)

With regard to professional teachers, in Article 8 and Article 9 of the Law of the Republic of Indonesia Number 14 of 2005 concerning Teachers and Lecturers it is determined that teachers are required to have a four-year bachelor's or diploma academic qualifications, pedagogical competencies, personality competencies, social competencies, professional competencies, educator certificates, physically and mentally healthy, and have the ability to realize national education goals.

Based on the results of interviews with Kandep (UPT) of Bandar Baru sub-district, Pidie Jaya Regency, Syarwan Hamid, it can be concluded that the indications of teacher performance are still very low and based on the results of preliminary studies in this study, it is found that the low performance of teachers can be seen from the initial study conducted by researchers of fifteen public elementary schools in Bandar Baru, Pidie Jaya Regency, as follows:

Table 1. Description of the Performance of Teachers of Public Elementary Schools in Bandar Baru Sub-District, Pidie Jaya District

\begin{tabular}{|l|l|c|}
\hline No & \multicolumn{1}{|c|}{ Description } & Percentage \\
\hline 1 & The teacher does not use technological media in learning & $50 \%$ \\
\hline 2 & Teacher work responsibilities are low & $40 \%$ \\
\hline 3 & The level of teacher discipline is low & $50 \%$ \\
\hline 4 & The teacher is lazy to update knowledge & $40 \%$ \\
\hline 5 & The teacher is not certified & $30 \%$ \\
\hline
\end{tabular}

Phenomena that show are, among others: (1) Teachers do not use technology media in learning $(50 \%)$, indicated by the large number of teachers who do not have learning media to teach in class. (2) The work responsibilities of teachers are low (40\%), indicated by teachers often late in completing their assignments. (3) The level of teacher discipline is low (50\%), indicated by teachers often arriving late and the number of teacher assignments not being carried out as they should. (4) Teachers are lazy to update their knowledge (40\%), indicated by the fact that there are still many teachers who do not attend training and educational 
seminars (5) Teachers have not been certified (30\%), indicated by the low willingness of teachers to meet the requirements for teacher certification due to factors age, busy with work and others.

In carrying out professional tasks, teachers are obliged to plan learning, carry out quality learning, and evaluate the learning process and results. Furthermore, teachers who have high performance will make the results of the learning evaluation as input on selfreflection activities in order to continuously improve the quality of learning. Professional teachers must always try to improve their abilities in accordance with the development of science and technology in order to conduct effective and efficient learning. Teachers' efforts to continuously improve their abilities are based on high organizational commitment to realize their personal goals in line with the goals of the organization (school).

In connection with teacher performance, Sudawan Danim (2016) states that: (a) teachers must behave professionally in carrying out the tasks of educating, teaching, guiding, directing, training, evaluating, and evaluating learning processes and outcomes; (b) teachers must guide students to understand, live and practice their rights and obligations as individuals, school members, and community members; (c) the teacher must recognize that each student has individual characteristics and each is entitled to learning services; (d) teachers must gather information about students and use it for the benefit of the educational process.

The results of Pangaribuan, Siburian, and Manullang (2016) research found that organizational culture, learning leadership, work motivation, and innovative behavior had a significant positive effect on the performance of school principals, where organizational culture, and learning leadership had direct and indirect effects on performance through work motivation and innovative behavior, while work motivation, and innovative behavior only have a direct influence on the performance of the principal. Wijaya Candra (2016) in her research found organizational culture and leadership behavior directly affect work effectiveness, while job satisfaction, job stress, and work motivation only have a direct influence on work effectiveness.

\section{Research Method}

The method used in this study is a survey method with a path analysis approach. In accordance with the research objectives, this research is explanatory. This is consistent with the Sitepu statement which explains that research aimed at determining the magnitude of the influence of a variable on other variables, both direct and indirect effects can be used path analysis if it is explanatory.

This research was carried out in the State Elementary School in Bandar Baru Subdistrict, Pidie Jaya District, and Aceh Province. The research was carried out for four months, two months to administer research permits, instrument trials, and refinement instruments. Furthermore, the last two months were used to collect data, analyze data, and write research report.

\section{Result and Discussion}

\subsection{Result}

The description of the data presented in this section includes data on Interpersonal Communication (X1), Job Satisfaction (X2) and Teacher Performance (X3). 


\section{a. Interpersonal Communication}

Based on the results of the study it can be seen that the respondents of 110 people (71.43\%) included in the good category, and as many as 44 people $(28.57 \%)$ included in the sufficient category. Thus, based on the achievement of the score above it can be concluded that the Interpersonal Communication of Public Elementary School Teachers in Bandar Baru Subdistrict, Pidie Jaya Regency tends to be in the high category.

\section{b. Job satisfaction}

Based on the results of the study it can be seen that the respondents as many as 46 people (29.87\%) included in the satisfied category, and as many as 100 people $(64.94 \%)$ included in the sufficient category, and 8 people $(5.19 \%)$ were in the unsatisfied category . Thus, based on the achievement of the above scores it can be concluded that the Job Satisfaction of Public Elementary School Teachers in Bandar Baru Subdistrict, Pidie Jaya Regency tends to be in the sufficient category.

\section{c. Teacher Performance}

Based on the results of the study it can be seen that respondents as many as 30 people $(19.48 \%)$ are included in the high category, as many as 88 people $(57.14 \%)$ are included in the sufficient category, and as many as 36 people $(23.38 \%)$ are in the poor category. Thus, based on the achievement of the score above it can be concluded that the Performance of Public Elementary Teachers in Bandar Baru Subdistrict, Pidie Jaya Regency tends to be in the sufficient category.

\subsection{Discussion}

\section{a. Interpersonal Communication has a Direct Positive Effect on Job Satisfaction}

Interpersonal communication has a direct positive effect on teacher job satisfaction in public elementary schools in Bandar Baru sub-district, Pidie Jaya District, meaning that if interpersonal communication gets better, it will increase teacher job satisfaction. This is based on testing the hypothesis with a path coefficient $\rho 41=0.369$ and $t=5.197$ with a significance level of 0.000 (the hypothesis is accepted if the significance level of t-count $<0.050$ ), so that the direct effect (direct effect) Interpersonal Communication on job satisfaction is 0.369 . Furthermore, based on the calculation results obtained by the total direct effect of Interpersonal Communication on job satisfaction of 0.136 or $13.6 \%$. So,Interpersonal Communication positive direct effect on Job satisfaction, amounting to $13.6 \%$ This shows that the better Interpersonal Communication, it will increase teacher job satisfaction.

The findings of this study are in accordance with the statement of Sutrisno (2009), who suggested that communication is a factor that affects job satisfaction. The findings of this study support the research of Siburian (2009), who found that interpersonal communication had a significant positive direct effect on teacher job satisfaction. Situmorang research results (2012), which found that job satisfaction is directly influenced by interpersonal communication. The findings of this study support the theory of Pace and Faules (2000), which explains that interpersonal communication has a direct effect on job satisfaction. Thus, the findings of this study, namely interpersonal communication directly have a significant positive effect on job satisfaction of elementary school teachers is in accordance with the results of research and the theory referred to in this study. 


\section{b. Interpersonal Communication has a Direct Positive Effect on Teacher Performance}

Interpersonal communication has a direct positive effect on the performance of elementary school teachers in Bandar Baru sub-district, Pidie Jaya district, meaning that if interpersonal communication is getting better, it will improve teacher performance. This is based on testing the hypothesis with a path coefficient $\rho 52=0.190$ and $t=3.142$ with a significance level of 0.002 (the hypothesis is accepted if the significance level of the $t$-value $<0.05$ ), so that the direct effect of Interpersonal Communication on Teacher Performance is 0.190 . Furthermore, based on the calculation results obtained by the total direct influence of Interpersonal Communication on Teacher Performance of 0.036 or $3.6 \%$ changes in Teacher Performance determined by Interpersonal Communication. The findings of this study are in accordance with the theories of Kreitner and Knicki (2007), which explains that communication has a direct effect on Teacher Performance. The findings of this study support research Winda (2009), which found Teacher Performance is directly influenced by interpersonal communication, Situmorang research results (2012) which found that interpersonal communication had a direct positive effect on Teacher Performance. Thus it can be stated that Interpersonal Communication is one of the supporting factors that can improve Teacher Performance. Therefore, Efforts that can be made to improve Teacher Performance can be done by increasing Interpersonal Communication. Thus, the findings of this study is interpersonal communication directly has a significant positive effect on elementary teacher performance is appropriate.

\section{c. Job Satisfaction has a Direct Positive Effect on Teacher Performance}

Based on the seventh hypothesis testing results obtained a significant path coefficient between Job Satisfaction with Performance, namely: p54 $=0.465$, and the results of the $t$ test $=6.780$ with a significance level of 0.000 (the hypothesis is accepted if the significance level of tcount $<0.050$ ), so that the direct effect of job satisfaction on Teacher Performance is 0.465. and based on the calculation results obtained direct influenceJob Satisfaction of Performance is 0.216 . So, Job satisfactionpositive direct effect on The performance, which is $21.60 \%$ changesThe performance can be determined by job satisfaction.

The findings of this study support the theory used as a basis for proposing theoretical models of research variables, namely the Theory of Baron and Greenberg (1990). The findings of this study are consistent with Muhadi's (2007) research results from Ambarit's research (2010) and Situmorang's (2012) research results, who found that job satisfaction had a significant positive direct effect on Teacher Performance. Sutji's research results (2009), which found that job satisfaction directly had a significant positive effect on the performance of high school principals.

Thus, the findings of this study conclude that job satisfaction directly has a significant positive effect on elementary school teacher performance in accordance with the results of the study and the theory referred to in this study.

\section{Conclusion}

Interpersonal communication has a direct positive effect on job satisfaction Public Elementary School Teacher In Bandar Baru Subdistrict, Pidie Jaya Regency. In other words the better interpersonal communication, the higher job satisfactionPublic Elementary School Teacher in Bandar Baru Subdistrict, Pidie Jaya Regency.

Interpersonal communication has a direct positive effect on performance Public Elementary School Teacher in Bandar Baru Subdistrict, Pidie Jaya Regency. In other words 
the better interpersonal communication, the higher the performancePublic Elementary School Teacher In Bandar Baru Subdistrict, Pidie Jaya Regency.

Job satisfaction has a direct positive effect on performance Public Elementary School Teacher In Bandar Baru Subdistrict, Pidie Jaya Regency. In other words, the higher job satisfaction, the higher the performancePublic Elementary School Teacher In Bandar Baru Subdistrict, Pidie Jaya Regency.

\section{References}

Aziz, Muhamad Abdul, (2017). Effect of Teacher Interpersonal Communication on Work Motivation in Achieving Teacher PerformanceMadrasah Aliyah Al-Falah 2 Nagreg Bandung, Journal of Garut University Education, Journal Vol. 11; No. 01. Bandung: Teen Rosdakarya.

Benyamin Situmorang, (2012). Influence of Organizational Culture, Leadership, Interpersonal Communication.

Candra Wijaya, (2016) The Influence of Organizational Culture, Leadership Behavior, Job Satisfaction, Stress and Job Satisfaction with the Principal's Organizational Commitment.

Directorate of Education Personnel, (2017). Academic Supervision in Improving Teacher Professionalism.

Doghan, Mohammed \& Sukaina, Albar. (2015). Influence of Motivation Factors on Employees Performance in Private Schools in Saudi Arabia. Journal of Human Resource and Sustainability Studies Vol.03, No. 4

Edy Sutrisno, (2009). Human Resource Management. Jakarta: Kencana.

Enco Mulyasa, (2018). Being a Professional Teacher Creates Creative and Enjoyable Learning.

Ibrahim Bafadal, (2016). Management of Elementary School Quality Improvement from Centralization to Decentralization. Jakarta. Earth Literacy Jakarta: Ministry of National Education.

Jason A. Colquitt, Jeffery A. LePine, and Michael J. Wesson. (2015). Organizational Behavior: Improving Performance and Commitment in the Workplace. New York: McGraw Hill.

Koesmono's friend. (2005). "The Effect of Organizational Culture on Motivation and Job Satisfaction and Employee Performance in the Medium Scale Timber Processing Industry Sub Sector in East Java". Journal of Management \& Entrepreneurship, 7, (2)

Kreitner, Robert and Angelo Kinicki. (2014). Organizational behavior. Translate. Jakarta: Salemba Empat.

Mahmudah Enny Widyaningrum. (2012). Effects of Organizational Culture And Ability On Organizational Commitment And Performance In Ibnu Sina Hospital Gresik, Academic Research International ISSN-L: 2223-9553, ISSN: 2223-9944 Vol. 2, No. 1, January 2012, Indonesia: Bhayangkara Surabaya University, 2012, p. 351

Muhadi, (2016). Analysis of the Effect of Job Satisfaction on Organizational Commitment in Influencing Employee Performance (Study on Employees) Dipanegoro University Administration, Thesis, Semarang: Postgraduate Program at Diponegoro University, Semarang.

Musarrat, Nawaz, Muhammad. (2016). Effects of Motivational Factors on Employees Job Satisfaction Case Study of the University of the Punjab, Pakistan. International Journal of Business and management Vol 5, No. 3 
Paningkat Siburian, (2009). Effect of Interpersonal Communication and Achievement Motivation on Job Satisfaction. Causal Studies at Parulian 2 Medan High School in 2009 (Medan: Post-Graduate Program

Rafida, T. 2018. Interpersonal Functions of Discourse Text in Chinese Ethnics, Medan, Indonesia. Budapest International Research and Critics Institute-Journal (BIRCIJournal) (1): 34-46.

Ramlan, et.al. 2020. The Effectiveness of Implementation of the MGMP Revitalization Program as a Media Increasing English Teacher Competency in Pidie District. BIRCIJournal,Volume 3, No 1, February 2020, Page: 95-103e-ISSN: 2615-3076(Online), pISSN: 2615-1715(Print) DOI: https://doi.org/10.33258/birci.v3i1.665

Ramlan, Farizawati, Hasrul, S. 2020. The Effectiveness of Implementation of the MGMP Revitalization Program as a Media Increasing English Teacher Competency in Pidie District. Budapest International Research and Critics Institute-Journal (BIRCIJournal) (3): 95-103.

Robert A. Baron, and Jerald Greenberg, (1990). Behavior in Organization: Understanding and Managing the Human Side of Work. Third Edition. Toronto: Allyn and Bacon Robert Kreitner and Angelo Knicki, (2007). Organizational Behavior. New York: McGraw Hill

RW Pace, and DF Faules. (200). Organizational Communication. Dedy Mulyana Bandung's translation: Teen Rosdakarya.

Senior Hign School Principals' Performance in Medan North Sumatra Indonesia", International

Shadare Oluseyi and Hammed T. Ayo (2009), "Influence of Work Motivation, Leadership Effectiveness and Time Management on Employees' Performance in Some Selected Industries in Ibadan, Oyo State, Nigeria", European Journal of Economics, Finance and Administrative Sciences ISSN 1450 -225 Issue 16

Situmorang Benjamin. (2012). The Effect of Organizational Culture, Leadership, Interpersonal Communication and Job Satisfaction on Organizational Commitment of School Principals (Case Study at Vocational Schools in Medan City). Dissertation (Medan: Postgraduate Program, State University of Medan

Sopiah (2008). Organizational behavior. Yogyakarta: Andi Publisher

Sudawan Danim, (2016). Teacher Professional Development From Pre-service, Induction to Professional Madani

Sutji Harijanto, (2009). The Influence of Organizational Culture, Leadership Styles, and Job Satisfaction on the Performance of High School Principals in East Jakarta (2009). Dissertation Synopsis (Jakarta: Jakarta State University Postgraduate Program

Syarifudin E, (2006). The Relationship between Work Motivation, Work Discipline, and Educational Leadership Knowledge with Principal Performance. Survey in SLTP-N Serang Regency, Banten Province. Dissertation Synopsis (Jakarta: Jakarta State University Postgraduate Program

Thariq, M. 2018. Interpersonal Communication Role for Selfconcept Of Children And Families. Budapest International Research and Critics Institute-Journal (BIRCIJournal) (1): 182-195.

Wanapri Pangaribuan, Paningkat Siburian, Jongga Manullang (2016), "Determining Factors of Wayne, Pace, and Don F. Faules. (2006). Organizational Communication. Dedy Mulyana's translation (Bandung: Youth Rosdakarya

Winda Pardipta Mastuti (2012). (http://karya-ilmiah.um.ac.id/index.php/BKPsychology/article/view/16723 Accessed January 14, 2012. 